\title{
A Research Project On Castism In India 'A Study on caste and the intensity of cased based prejudices among people of various economics levels in Travancore'
}

\author{
Gayathree P Thampi \\ Semester II - BA LLB Dr Ram Manohar Lohiya National Law University \\ Sec- D1, LDA Colony, Kanpur Road Scheme, Lucknow, Uttar Pradesh India
}

\begin{abstract}
India is well known for its complicated system of caste and its own indigenous system of social division. The caste based prejudices vary from a ban on marriages to untouchability. Even in the $21^{\text {st }}$ century, India is far from salvation. Kerala, which is the state which was under the research survey, proved to be one of the 'forward' states when it came to inter-caste marriages. It has one of the highest numbers of inter-caste and inert-religious marriages. The question is how worst is the best?
\end{abstract}

Keywords: Kerala, caste in India, caste and economics, Travancore, caste based rejudices, education and caste.

\section{Introduction}

Travancore used to be one of the richest princely states of Kerala and one of the very first princely state in India to modernize educational standards and to receive the 'neo- liberal' ideologies of the new era. The whole project shows the transition of an adamant caste based society into a secular and tolerant one. The whole project is based on the caste system of the princely state of Travancore. Travancore is ruled by kings who have sworn their swords to the God Sree Padmanabhaswamy. The liberation from the caste based prejudices essentially began from the 'Temple Entry Proclamation' by the king which allowed everyone to worship in any of the temple under the royal rule, without any bias of caste or religion. This was a landmark in euphemizing the caste barriers.

\section{Hypothesis}

- Caste system is not uniform all over Kerala, though there is a rough and common pattern of hierarchy seen.

- Caste based prejudices are lesser among the well educated while illiterate stick to the caste system and the social rules around it.

- Caste based prejudices are more in poor people than in rich people.

- Caste based prejudices are more in rural areas than in urban areas.

\section{Caste structure of Travancore dynasty}

Caste structure in Kerala is complicated with caste and sub castes each with their own definite place in the hierarchy and this caste structure varies from district to district and meddling with this complex structure is the people of same caste but different religion. Swami Vivekananda called Kerala 'a madhouse of castes'. Adding to the confusion is the fact that some castes, though are classified as shudra, were the rulers and novelties and were treated a kshetriyas. Caste system in Kerala can be explained by dividing the state of Kerala into princely states that existed before independence. Kerala back then was divided into Travancore, Cochin and Malabar province. Caste system in Kerala is primarily based on the type of jobs each group does. Compared to other states of India, caste based prejudices and adherence to caste system is least seen in Kerala. In this project we would primarily focus on Tranvancore princely state.

Travancore province primarily contained parts of Kanyakumari district of Tamil Nadu, Trivandrum capital district of Kerala, and parts of Kollam district.

\section{Brahmins}

The temple Brahmins were the ones who did rituals and idol worship in the temples. A sub caste system includes Vaithi Brahmins, Nambees, Namboothirees and Iyers. Namboothirees hail from Karnataka while rest all belong to Tamil Brahmin category. Vaithi Brahmins are the chefs who primarily took care of the temple feast and food to be offered for the deities. Nambees were the supervisor or the overseer of the temple. 
Namboothirees and Iyer Brahmins were the temple Brahmins who did the rituals and performed the idol worships. They were the ones well versed with Vedas. There was also a class of Brahmins called Konkani Brahmins. They spoke the language of Konkani and had their own elaborate culture and traditions. They are not temple Brahmins but migrants from Karnataka. They are considered a clan lower to other Brahmins. Only the eldest of the family was allowed a legal marriage. Rest of all the brothers, were only allowed to keep consorts.

\section{Nair}

Nair is one of the main castes in Travancore. In fact Nairs are in majority and has an elaborate system of sub castes which varies from ruling class to the working class. The ruling class is Varmas who are the kings. They are followed by Thampis who are the first class nobles. They are the king's in laws and did ministerial job. It was traditional for the king to have consorts from prominent Nair landlord families. They were given the position of Thampis who were meant to rule over the provinces. They were the only class other than the king who were allowed palanquins in Travancore.

Since the society adhered strictly to Marumakkathayam, the inheritance was by the nephew and not son. This is the reason why sons of kings were nobles where as children of king's sisters were crowned as the king. Marumakkal in Malayalam translated to nephews. In this system, sister's children inherited all the property and assets and not sons. The reason for prominence of Marumakkathayam is because of the fact the Nairs followed 'Sambanda' system were Nair ladies served as consorts to Brahmins and the ruling class and also the system of primae noctis was prevalent. Hence paternity was always in question.

Maternity was viewed as the only surety. Next would be the Nair sub category of Pillas, Menon, Nambiars and Kurups. They are the plantation managers of the Nair landlords.

Nairs were primarily Dravidian clan who worshipped serpents as the clan protectors. Nairs also served as the military class and were called 'Nair Pattalam'. Warriers and Marars are the temple Nairs who does cleaning up and garland making in the temples. Marars are traditionally the instrument players during the time of rituals. Nairs were also the labour class or the Shudras. For example, Chekala, vilakkithala, veluthedathu and Pandaras are the sub castes of Nairs who are considered to be lower class people. They are respectively the oil merchants, barbers, launderers and the curds makers.

\section{Ezhavas}

Ezhavas as basically small scale businessmen, toddy makers or agricultural laborers. But they are well known for liquor making and liquor business. It is believed that they were invited to Kerala from Ceylon by the landlords to make toddy. They have also their role in the king's army. Ezhava customs and traditions are similar to that of Nairs. They are considered as backward class.

\section{Nadars}

The Nadar community was not a single caste, but developed from an assortment of related sub castes and classes of different origins, which in course of time, came under the single banner Nadar. ${ }^{[3]}$ Nadar climber was the largest sub sect of today's Nadar community. ${ }^{[4]}$

A few sub sects of the Nadar community, such as the Nelamaikkarars, were traditionally wealthy landlords and money lenders. ${ }^{[5]}$ The martial art of Southern Kalaripayattu was historically practiced by the Nadars. ${ }^{[7]}$ Traditionally, lower caste women, including that of Nadars, did not have the right to wear clothes on the upper half of their body. This was later changed after a revolt that arose during the British era.

\section{Kaani}

Kaanis are the tribal class in Kerala. They have led a secluded life since centuries and were the last to participate in the political and cultural renovations of Kerala. Kaanis practiced traditional ayurvedic methods and is said to know many herbal single medicine therapies.

They are Shakthi worshippers and practice the occult. They do sacrificial rituals and are known for their own indigenous dance and art forms.

\section{Arayar}

Arayars are traditional fishermen of Travancore. They are confined exclusively to the coastal regions and an interesting thing is that it is the only prominent caste that you see in the coastal region. They are seen as a backward class.

\section{Scheduled castes of Travancore}

Scheduled caste or the untouchables include Paraiyar, Pulayar, Chandala, Chamar, Cheraman, Koravar, Kakkalar, Mannans, Thandans, Velans and 58 other castes ${ }^{[5]}$. They are basically the landless labour class or the basket weavers, or potters etc. 


\section{Other castes}

Other caste include Kollan (the blacksmith), Chetty (the trader), Vaniyan (the oil merchant), Aasari /Vishwakarma (the carpenter/ builder), Thattan (the goldsmith), Chaliyar (the weavers) etc. These are basically job based caste systems with their own elaborate sub caste system.

[1] Gazetteers of India Tamil Nadu state: Thoothukudi district by Sinnakani: Page 233-242

[2] Sinnakani, Tamil Nadu State: Thoothukudi District, Volume 2, Government of Tamil Nadu, Commissioner of archives and Historical Research. pp. 233-242.

[3] Hardgrave, Robert, The Nadars of Tamilnad: the political culture of a community in change, Berkeley: University of California Press, 1969, pp. 29-34

[4] Thomas A. Green, Martial arts of the world: en encyclopedia, A - Q, Volume 1, 2001, ABC-CLIO, Inc. p. 177

[5] <http://www.old.kerala.gov.in/dept_sc/listofcastesinclud.htm>, last accessed 0n 04/03/2014

\section{A study on intensity of caste based prejudices}

Caste based prejudices vary with regions. In certain regions two castes are seen in par with certain other and inter-caste marriages are forgivable. The same castes in inter caste marriage in a different regions are seen unforgivable.

Before the dawn of $20^{\text {th }}$ century, Mannapedi, Pulapedi are the names of two customs that prohibited women from upper class from going out on a certain day of the year when the landless labour castes are given independence. On that day, if a landless laborer happens to touch a higher caste girl, or even throw a stone at her, she was thrown out of her house by ritually performing her death ceremony and would be condemned to spend her life with the lower castes, in their poverty as one of them Mannan and Pulayar are two lower castes and 'Pedi' in Malayalam means fear. That was the only day when the higher class feared the lower. If a cow of the higher caste household dies of some disease, the carcass of it belong to the lower caste.

If ever a lower caste farms something in his meager land, the landlord's manager would be there to take away the produce. There was also a rule that lower caste women are prohibited from covering the upper half of their body. The rich landlords and Brahmins carried a bell with them which they rand as they walked. This was a warning bell for the lower caste people to hide before the higher class saw them.

The starting of caste abolition in Travancore started not with the untouchability abolition act but with the proclamation of 'Kshetra Praveshana Vilambaram' by then ruling king Chitra Thirunal Marthanda Varma Maharaja. It gives people of all castes right to worship in all the temples under the rule of Travancore dynasty. Since then untouchability was unheard in the princely state of Travancore. Even though in some states of Kerala, even now, the royal families do not allow lower castes to enter the house, Travancore saw a princely model of secularism about half a century back.

An interview with Sadanandan, an 83 - year old tea shop owner proves this assertion. He is of the Pulayar community, having lived all his life as a landless laborer for most part of his life. He is father to five children, three sons and two daughters. All his children are working, four in government posts and one owning a fertilizer shop and ration shop. Sadanandan does not have even primary education. On being asked about his youth, he says:

"My dad was a landless laborer in the fields of the then land lord. Food is mainly 'Kanji' (a variety of rice porridge) and anything more was a luxury which we might get during Onam and Vishu (the harvest and new-year festival of Kerala). Father would bring rice every day, with him in the evening, which mother would cook for us. I don't have the memory of stomach full of meal even once in y childhood. The Nazhi (a glass) of rice was to feed a family of 13 , including all my siblings. We used to steal from the nearby Tapioca plantation. If caught, it would have cost us our lives. Water came from the channels and to touch the well of the landlord's house meant death or exile. I and my brothers used to help my father ever since we turned 10. Mother used to collect palm leaves and plait them into sheets and sell them for money. Lower caste people were not allowed to take part in public functions or enter into the household of a higher class."

76 year old Vasanthi Amma, who was the landlord's daughter, whom the Sadanandan was referring to, on asking about her youth and what she perceived of the life of lower caste people, replied thus:

"There was nothing special about my youth. Not counting the technological advances, it was pretty much similar to any other youth in the village. We were not allowed to go out much. So I cannot give you the broader view of things. I had my education done in our own school. After my SSLC, I was married off to another family. My husband was of a higher sub caste but since financially we were equals and so the marriage was done. There was nothing as the caste system. The lower caste was not allowed inside the house. They used to bring us fish or mutton occasionally and would be there during harvesting time and when we gave away food to the poor during special days of the year. They were in large numbers, from very small to very old; all would be there with their plates. One has to careful with them around, because they were artful thieves." 
What essentially shown here is the difference in perception in the same matter but by two extremes of the society. From the various perceptions, both extreme as well as euphemistic, we can safely conclude that there existed a strong and strict caste based prejudice in Travancore.

\section{Inter-caste marriages in Travancore- education}

To a very large extend, time has euphemized caste based prejudices in marriages enough to not mind sub caste differences, even though most of the times, it is often received with a scorn. In the last 25 years, there was a boom in the number of inter caste marriages especially with Nair and Ezhava families.

On being asked about inter-caste marriages and social attitude about it, Unnikrishnan Nair, as 52 year old scientist working in VSSC, answers thus.

"Caste system existed during my youth but it wasn't as how the books portrayed it. We did not encourage inter-caste marriages but if a two people of different caste decided to be together, the best we would do is to deny the inherited properties to them. There were lot of inter-caste marriages among my friends also and no protests as such were there. I personally would not mind my own son marrying a girl of different caste as long as he does not get a scheduled caste girl or an illiterate one into the family."

Kerala remains the state with highest number of inter-caste marriages, along with Maharashtra and Goa. Kerala clocked 2,454 inter-caste marriages in the year 2013, a healthy jump from 1,040, 1,000 and 996 in the previous three years. ${ }^{[6]}$ In Kerala, it is therefore safe to assume that caste based prejudices are very much less stronger than economic and educational standards. Most parents do not mind inter-caste marriages as long as the children go for better educated or financially well off partners. In interesting trend seen while interviewing 15 different people of ages 30-50 of three different educational backgrounds i.e. 5 below SSLC education (A), 5 with Bachelors (B) and 5 with masters or more (C).

The people of A category, was adamant about same caste marriage, as expected. People of B category, were comparatively more lenient towards inter-caste marriage. The contradiction to expectation happened in the $\mathrm{C}$ category. $\mathrm{C}$ category offers most resistance to inter-caste nuptials. They are more adamant on same caste marriage than the other two categories.

[6] Ghildiyal, Subodh, 'Steady rise in inter-caste marriages involving dalits', The Times of India, 09/19/2013,

$<$ http://timesofindia.indiatimes.com/india/Steady-rise-in-inter-caste-marriages-involving-

dalits/articleshow/22728944.cms>, last accessed on 03/09/2014

\section{Relation between economic status and caste}

Caste and economic status had a negative relation as far as anyone can remember. With money comes the issue of status and especially, money with higher caste people meant strict adherence to caste based prejudices so that they can boost their egos. While if it is the lower caste group that is rich, then instead of trying to overcome the caste barriers they specifically tired to jump to the so called 'elite caste' group by betrothal. An interesting trend seen is that higher the economic status of the family, more will its inclination be towards the elite group and its contempt for the lower caste group.

The concept of urbanization has done much change to this system. The very reason the state of Kerala has more inter caste marriages and least of caste based prejudices are because of the fact that westernization and urbanization is well received in these states. In Kerala, you find a number of cultures including Anglo Indians, Jews, French, and Portuguese etc. This is due to the fact that more than half of Kerala boundary is lined with coastal shores which are well apt to be ports. This helped in more than trade. There was a great deal of cultural exchange that took place. This cultural exchange has had more than a mere role in eliminating the caste barriers and the prejudices that followed it. Therefore, it is evident that rural villages of Travancore are more adamant on caste based prejudices. But this is a generalization based on the figures. Rural villages which are occupation oriented like farming village or the local market sees fine intermingling of Ezhavas, Nairs and Nadars to the extent of nuptial ties.

Caste System varies in different parts of Kerala, each based on the geographical and meteorological factors of the land, the basic occupations that the people follow and the history related with the land. Though the survey is primarily done in the Princely state of Travancore, the results of the survey and interviews are mostly general and the aforesaid patterns of caste intensity is seen all over Kerala and can even be generalized to India as a whole.

\section{Research Methodology}

\section{Coverage}

This project studies the intricacies of caste system in a particular region of Kerala and does an analytical and comparative study of the intensities of cased based prejudices in various sections of the society. 


\section{Data collection}

The date collected is primarily analytical in nature which makes use of surveys to reach its conclusion. There is also a descriptive part which explains the concepts introduced in the essay.

\section{Sources} resources.

This project makes use of both primary and secondary sources like articles, books and internet

\section{Conclusion}

What essentially discriminates the country of India, from other nations is the variety of caste and its hierarchy in the society. India being secular supports many religions and each with its own variety of clan and groups. Caste system was the root causes for many a crime against humanity that has been committed in India, during the pre-colonial era. It is indeed much consoling to note that much of the caste system and its hierarchical segregation and discrimination have worn off due to the advent of the western culture and urbanization. Economic status always favors the elite. Instead of helping to euphemize the intensity of caste based prejudices, it further aggravates it. Higher the economic ability of a family, higher is their wish to join the elite class by means of nuptial ties. Education also has a very negative impact on caste system. It is seen that the highly educated favors caste system and adhere strictly to it while middle class has more tolerant attitude towards it. Urbanization has helped a great deal to encourage inter caste betrothals and intermingling of people.

\section{Acknowledgment}

This Project is a bonafide record of all the data collected pertaining to the topic, arranged and expressed to the best of my abilities. I, hereby thank Mr. Manwendra Kumar Tiwari, my guiding light and inspiration, for believing in me and Dr. Sanjay SIngh for the support. Most importantly I thank Lord almighty and my parents for their love, blessings and support.

\section{References}

[1] Gazetteers of India Tamil Nadu state: Thoothukudi district by Sinnakani: Page 233-242

[2] Sinnakani, Tamil Nadu State: Thoothukudi District, Volume 2, Government of Tamil Nadu, Commissioner of archives and Historical Research. pp. 233-242.

[3] Hardgrave, Robert, The Nadars of Tamilnad: the political culture of a community in change, Berkeley: University of California Press, 1969, pp. 29-34

[4] Thomas A. Green, Martial arts of the world: en encyclopedia, A - Q, Volume 1, 2001, ABC-CLIO, Inc. p. 177

[5] <http://www.old.kerala.gov.in/dept_sc/listofcastesinclud.htm>, last accessed 0n 04/03/2014

[6] Ghildiyal, Subodh, 'Steady rise in inter-caste marriages involving dalits', The Times of India, 09/19/2013, $<$ http://timesofindia.indiatimes.com/india/Steady-rise-in-inter-caste-marriages-involving-dalits/articleshow/22728944.cms>, last accessed on 03/09/2014

[7] Alappatt, Sreedhara Menon, Kerala Charitram and samskaram, D C Books, 2013

[8] Alappatt, Sreedhara Menon, 'Triumph and Tragedy in Travancore: Annals of Sir CPs Sixteen Years' Current Books, 2001 